DOI: 10.17707/AgricultForest.61.3.15

\author{
Dragoljub MITROVIC, Radisav DUBLJEVIC, \\ Nebojsa DJORDJEVIC, Velibor SPALEVIC, Dijana STIJEPOVIC ${ }^{l}$
}

\title{
ENERGY USE IN MECHANIZED PRODUCTION OF SILAGE
}

\begin{abstract}
SUMMARY
The paper presents the results of tests of machines in silage corn. The experiments were carried out under production conditions in 2012/2013 on the farm of the family Cunmuljaj in the village of Podhum, Tuzi, the periphery of Podgorica in Montenegro. The main objective was the assessment of the optimal parameters of productivity, work quality, and energy consumption in manufacturing and storing of silage. Working speed of the machine and tractors aggregate (TMA) was studied; its productivity, as well as energy and fuel consumption. To review the effectiveness of the various tests chronometric method was applied. Hand-held stopwatch was used for the speed measuring of the individual farming operations: basic tillage, application of mineral fertilizers, supplemental tillage, sowing, cultivation of crops, weed control and plant disease, irrigation, silage of plant mass, transport of silage mass and compaction of silage. Sowing of corn silage is done with the tractor aggregate $(\mathrm{P}=28 \mathrm{~kW})$, with the row spacing between the plants of $70 \mathrm{~cm}$; the distance $18 \mathrm{~cm} ; 75000$ plants per hectare, with the average of $281 \mathrm{ha}^{-1}$; energy consumption of $1148 \mathrm{MJ}$ $\mathrm{ha}^{-1}$. In the tillage the diesel fuel consumption amounted of $12.81 \mathrm{ha}^{-1}, 524.8 \mathrm{MJ}$ $\mathrm{ha}^{-1}$ respectively. With the application of mineral fertilizers, the average consumption of diesel fuel stood at $0.551 \mathrm{ha}^{-1} ; 22.55 \mathrm{MJ} \mathrm{ha}^{-1}$ respectively. The highest consumption of diesel fuel was achieved with the ensiling of plant mass, which was in average $88.61 \mathrm{ha}^{-1}$, which represents the energy consumption of $3632 \mathrm{MJ} \mathrm{ha}^{-1}$. The total consumption of diesel fuel amounted $2131 \mathrm{ha}^{-1} ; 8741.2$ $\mathrm{MJ} \mathrm{ha}^{-1}$, with the yield of $66.840 \mathrm{~kg} \mathrm{ha}^{-1}$, and the energy value of $374304 \mathrm{MJ}$.
\end{abstract}

Keywords: land, processing, harvesting, cultivation, silage, fuel, energy.

\section{INTRODUCTION}

Silage is fermented, high-moisture stored fodder which can be fed to ruminants (cud-chewing animals such as cattle and sheep) or used as a biofuel feedstock for anaerobic digesters (Wood, 1997). It is fermented and stored in a process called ensilage, ensiling or silaging, and is usually made from grass crops, including maize, sorghum or other cereals, using the entire green plant (not just the grain). Silage can be made from many field crops, and special terms

\footnotetext{
1 Dragoljub Mitrovic (corresponding author: drd_mitrovic@yahoo.com), Radisav Dubljevic, Nebojsa Djordjevic, Stijepovic Dijana, University of Montenegro, Biotechnical Faculty, Velibor Spalevic, Institute of Forestry, Podgorica, MONTENEGRO.

Note: The authors declare that they have no conflicts of interest. Authorship Form signed online.
} 
may be used depending on type such as oatlage for oats, haylage for alfalfa (Ronald, 1994).

Silage is made either by placing cut green vegetation in a silo, by piling it in a large heap covered with plastic sheet, or by wrapping large bales in plastic film.

Preservation of silage can be done during the lactic acid fermentation process. Preparation of the silage can be carried out using mechanization with full synchronization of all phases of work. Silage solves the problem of feeding and storage of fodder production. Bulk density silage of legumes ranges from $700-1000 \mathrm{~kg} \mathrm{~m}^{-3}$ bulk density of non- baled hay of $50-60 \mathrm{~kg} \mathrm{~m}^{-3}$ and baled hay from 120-250 $\mathrm{kg} \mathrm{m}^{-3}$ (Mitrovic, 2012).

Technological process of ensiling is based on the transformation of soluble carbohydrates of plant-silage of at least $10 \%$ of dry matter. The principle of ensiling is based on the transformation of water soluble carbohydrates, which must transformed at least $10 \%$ of the dry matter in lactic acid. This is achieved in an anaerobic environment, by work of anaerobic lactic acid bacteria, and other microorganisms, with adequate moisture, $65-70 \%$ in forages and $33-38 \%$ in the concentrated feed (Dinic and Djordjevic, 2005) and temperature $\left(35-38^{\circ} \mathrm{C}\right)$.

The silage is the most appropriate replacement of green feed additives and animal feed achieves the maximum preservation of the quality and nutritional value of forage, which is of particular importance for savings of expensive additional animal nutrition concentrated fertilizers.

Silage corn is preserving the quality of the green mass and is the most common corn silage (rich in energy), in combination with suitable types of grass silage. Haylage is rich in proteins and in combination with maize silage gets high quality basic meal for cattle. The average yield of biomass with $45 \%$ humidity in the working process was $9.54 \mathrm{tha}^{-1}$, and after completing the process of ensiling is obtained with an average feed metabolic energy (ME) of $4.5 \mathrm{MJ} \mathrm{kg}^{-1}$, which is 42.930 MJ of ME per hectare (Jugovic, 2012).

On larger farms, feeding of the livestock is based in saving daily ration hay, fresh green mass and silage. As an illustration on the farm of 500 cows with an average portion of $40 \mathrm{~kg}$ of silage per head, in the winter of 6 months is necessary to provide around 3600 tons of silage (Lulo, 1984).

The knowledge of improved techniques for forage harvesting and preservation has drastically increased during the latest decades (Helander, 2014). Silage of high crops (maize, sorghum, soybeans) on major production areas is carried out with a multi-row self-propelled forage harvester, and in smaller areas silage is made with single-row and double-carriage of the combine to the tractor drive.

\section{MATERIAL AND METHODS}

The experiments were carried out under production conditions in 2012/2013 on the farm of the family Cunmuljaj in the village of Podhum, Tuzi, the periphery of Podgorica in Montenegro $\left(42^{\circ} 18^{\prime} 40.0^{\prime \prime} \mathrm{N} ; 19^{\circ} 20^{\prime} 04.0^{\prime \prime} \mathrm{E}\right)$. 
The efficiency evaluation of the testing regimes were conducted using chronometer measurements (hand-held stopwatch) of individual farming operations: basic tillage, incorporation of mineral fertilizer, supplemental tillage, sowing, cultivation of crops, plant protection disease and pest control, irrigation, plant mass ensiling corn silage mass transport and compaction (trampling) silage in the silo trench. Sowing of corn silage is done with the tractor aggregate $(\mathrm{P}=28 \mathrm{~kW})$, with the row spacing between the plants of $70 \mathrm{~cm}$; the distance $18 \mathrm{~cm}$; 75.000 plants per hectare. The production and storage of silage corn are presented in the Tab 1.

Table 1. Working operations in the production and storage of silage

\begin{tabular}{|l|l|l|}
\hline Working operations & Power Machines & Supply machines \\
\hline Primary treatment & Tractor, $\mathrm{P}=31 \mathrm{~kW}$ & Double plow \\
\hline Fertilizer & Tractor, $\mathrm{P}=28 \mathrm{~kW}$ & Carried spreader $\mathrm{V}=450 \mathrm{~L}$ \\
Additional processing & Tractor, $\mathrm{P}=31 \mathrm{~kW}$ & Tiller $\mathrm{rz}=1,45 \mathrm{~m}$ \\
\hline Sowing & Tractor, $\mathrm{P}=28 \mathrm{~kW}$ & Mechanical seeders 2-row \\
\hline Cultivation & Tractor, $\mathrm{P}=31 \mathrm{~kW}$ & Cultivator 3-row \\
\hline Protection & Tractor, $\mathrm{P}=28 \mathrm{~kW}$ & Mounted sprayer $450 \mathrm{~L}$ \\
\hline Irrigation & Electric pump & Sprinklers \\
Silage of plant mass & Tractor, $\mathrm{P}=44 \mathrm{~kW}$ & Single-row harvester \\
Transp. ensiled plant material & Tractor, $\mathrm{P}=28 \mathrm{~kW}$ & Single axle trailer $5 \mathrm{~m}^{3}$ \\
\hline Compacting ens. plant material & Tractor, $\mathrm{P}=31 \mathrm{~kW}$ & \\
\hline
\end{tabular}

Technical aggregate productivity and energy consumption in some labor is determined on the basis of mathematical equations:

\section{Technical aggregate productivity:}

$\mathrm{W}_{\mathrm{th}}=0.1 \times \mathrm{B} \times \mathrm{v} \times \mathrm{n}\left(\mathrm{ha} \mathrm{h}^{-1}\right)$;

$\mathrm{B}$ - Working intervention unit (m)

$\mathrm{v}$ - Working speed unit $\left(\mathrm{km} \mathrm{h}^{-1}\right)$,

$\eta$ - Coefficient of utilization of working clearance aggregates.

\section{Working speed unit:}

$\mathrm{V}_{\mathrm{r}}=\frac{5 \mathrm{r}}{\mathrm{Tr}}$

$\mathrm{Sr}$ - length of section work times $(\mathrm{m}, \mathrm{km})$;

$\mathrm{Tr}$ - technological - useful time spent in going over working times (h).

\section{Energy consumption (Eha):}

\section{$\frac{P_{v}}{W_{h}}\left(\mathrm{kWh} \mathrm{ha}^{-1}\right)$}

\section{Technological fuel consumption:}

$\mathrm{q}_{\mathrm{g}}=\mathrm{G}_{\mathrm{r}} / \mathrm{W}_{\mathrm{r}}$

$\mathrm{q}_{\mathrm{g}}=\mathrm{G}_{\mathrm{r}} / 0.1 . \mathrm{B}_{\mathrm{r}} \cdot \mathrm{v}_{\mathrm{r}}\left(\mathrm{kg} \mathrm{ha}^{-1}, 1 \mathrm{ha}^{-1}\right)$

$\mathrm{G}_{\mathrm{r}}$ - hour fuel consumption $\left(\mathrm{kg} \mathrm{h}^{-1}, \mathrm{l} \mathrm{h}^{-1}\right)$,

$\mathrm{W}_{\mathrm{r}}$ - aggregate productivity $\left(\mathrm{ha} \mathrm{h}^{-1}\right)$,

$\mathrm{B}_{\mathrm{r}}$ - width unit (m),

$\mathrm{V}_{\mathrm{r}}$ - The operating speed of aggregates $\left(\mathrm{km} \mathrm{h}^{-1}\right)$. 


\section{Absolute fuel consumption: $\mathbf{Q a}=\mathbf{Q u} / \mathbf{h}(\mathrm{l})$}

Qa- absolute fuel consumption (1),

$\mathrm{Qu}$ - the total amount of fuel consumed (l),

h- number of working hours (h).

\section{Specific fuel consumption (Qs):}

$\mathrm{Qs}=\mathrm{g} / \mathrm{kWh}(\mathrm{g})$

Qs- specific fuel consumption (g),

$\mathrm{g}$ - the amount of fuel $(\mathrm{g})$,

$\mathrm{kWh}$ - power $(\mathrm{W})$.

\section{Fuel consumption per unit of work performed:}

$\mathrm{Qr}=\mathrm{Qu} / \mathrm{W}\left(\mathrm{ha}^{-1}\right),\left(\mathrm{l} \mathrm{t}^{-1}\right),\left(1 \mathrm{~m}^{-1}, \mathrm{ha}, \mathrm{t}, \mathrm{m}^{3}\right)$

Qr- fuel consumption per unit of work performed $\left(\mathrm{ha}, \mathrm{t}, \mathrm{m}^{3}\right.$ ),

$\mathrm{Qu}$ - the total amount of fuel consumed (1)

$\mathrm{W}$ - aggregate productivity

Energy consumption: the Energy value of diesel fuel (41 $\left.\mathrm{MJ}^{-1}\right)$ and the energy value of the silage $\left(5.6 \mathrm{MJ} \mathrm{kg}^{-1}\right)$.

\section{RESULTS AND DISCUSSION}

Exploitation and energy research results in aggregate production and silage are shown in the table $2 \mathrm{a}-\mathrm{g}$.

Tab 2a Exploitation \& energy indicators of operation of the unit - basic soil tillage

\begin{tabular}{|c|c|c|c|c|c|c|}
\hline $\begin{array}{c}\text { The } \\
\text { unit in } \\
\text { basic } \\
\text { soil } \\
\text { tillage }\end{array}$ & $\begin{array}{c}\text { Working } \\
\text { speed } \\
\text { unit } \\
\left(\mathrm{km} \mathrm{h}^{-1}\right)\end{array}$ & $\begin{array}{c}\text { Fuel } \\
\text { consumption } \\
\left(1 \mathrm{~h} \mathrm{~h}^{-1}\right)\end{array}$ & $\begin{array}{c}\text { Fuel } \\
\text { consumption } \\
\left(1 \mathrm{ha}^{-1}\right)\end{array}$ & $\begin{array}{c}\text { Energy } \\
\text { consumption } \\
\left(\mathrm{MJ} \mathrm{ha}^{-1}\right)\end{array}$ & $\begin{array}{c}\text { Working } \\
\text { width } \\
(\mathrm{m})\end{array}$ & $\begin{array}{c}\text { Technical } \\
\text { productivity } \\
\left(\text { ha h }^{-1}\right)\end{array}$ \\
\hline $\mathrm{X}_{\mathrm{sr}}$ & 4.8 & 4.2 & 28.0 & 1.148 .0 & 0.45 & 0.15 \\
\hline
\end{tabular}

Tab 2b Exploitation and energy indicators of operation of the unit in tillage

\begin{tabular}{|c|c|c|c|c|c|c|}
\hline $\begin{array}{c}\text { Aggregate } \\
\text { in } \\
\text { tillage }\end{array}$ & $\begin{array}{c}\text { Working } \\
\text { speed } \\
\text { unit } \\
\left(\mathrm{km} \mathrm{h}^{-1}\right)\end{array}$ & $\begin{array}{c}\text { Fuel } \\
\text { consumptio } \\
\mathrm{n} \\
\left(\mathrm{l} \mathrm{h}^{-1}\right)\end{array}$ & $\begin{array}{c}\text { Fuel } \\
\text { consumptio } \\
\mathrm{n} \\
\left(\mathrm{l} \mathrm{ha}^{-1}\right)\end{array}$ & $\begin{array}{c}\text { Energy } \\
\text { consumptio } \\
\mathrm{n}\left(\mathrm{MJ} \mathrm{ha}^{-1}\right)\end{array}$ & $\begin{array}{c}\text { Working } \\
\text { width } \\
(\mathrm{m})\end{array}$ & $\begin{array}{c}\text { Technical } \\
\text { productivit } \\
\mathrm{y} \\
\left(\mathrm{ha} \mathrm{h}^{-1}\right)\end{array}$ \\
\hline $\mathrm{X}_{\mathrm{sr}}$ & 3.5 & 4.6 & 12.8 & 524.8 & 1.45 & 0.36 \\
\hline
\end{tabular}

Tab 2c Exploitation and energy indicators of operation of the unit in the use of mineral fertilizers

\begin{tabular}{|c|c|c|c|c|c|c|}
\hline $\begin{array}{c}\text { Aggregate } \\
\text { the dissip. } \\
\text { of min. } \\
\text { fert. }\end{array}$ & $\begin{array}{c}\text { Working } \\
\text { speed } \\
\text { unit } \\
\left(\mathrm{km} \mathrm{h}^{-1}\right)\end{array}$ & $\begin{array}{c}\text { Fuel } \\
\text { consumption } \\
\left(1 \mathrm{~h} \mathrm{~h}^{-1}\right)\end{array}$ & $\begin{array}{c}\text { Fuel } \\
\text { consumption } \\
\left(1 \mathrm{ha}^{-1}\right)\end{array}$ & $\begin{array}{c}\text { Energy } \\
\text { consumption } \\
\left(\mathrm{MJ} \mathrm{ha}^{-1}\right)\end{array}$ & $\begin{array}{c}\text { Working } \\
\text { width } \\
(\mathrm{m})\end{array}$ & $\begin{array}{c}\text { Technical } \\
\text { productivity } \\
\left(\mathrm{ha} \mathrm{h}^{-1}\right)\end{array}$ \\
\hline $\mathrm{Xsr}$ & 6.1 & 2.8 & 0.45 & 18.45 & 14.0 & 5.12 \\
\hline
\end{tabular}


Tab 2d Exploitation and energy parameters of a unit in sowing maize

\begin{tabular}{|c|c|c|c|c|c|c|}
\hline $\begin{array}{c}\text { The unit } \\
\text { in sowing } \\
\text { maize }\end{array}$ & $\begin{array}{c}\text { Working } \\
\text { speed unit } \\
\left(\mathrm{km} \mathrm{h}^{-1}\right)\end{array}$ & $\begin{array}{c}\text { Fuel } \\
\text { consumption } \\
\left(1 \mathrm{~h}^{-1}\right)\end{array}$ & $\begin{array}{c}\text { Fuel } \\
\text { consumption } \\
\left(1 \mathrm{ha}^{-1}\right)\end{array}$ & $\begin{array}{c}\text { Energy } \\
\text { consumption } \\
\left(\mathrm{MJ} \mathrm{ha}^{-1}\right)\end{array}$ & $\begin{array}{c}\text { Working } \\
\text { width } \\
(\mathrm{m})\end{array}$ & $\begin{array}{c}\text { Technical } \\
\text { productivity } \\
\left(\mathrm{ha} \mathrm{h}^{-1}\right)\end{array}$ \\
\hline $\mathrm{Xsr}$ & 4.2 & 2.8 & 8.0 & 328.0 & 1.4 & 0.35 \\
\hline
\end{tabular}

Tab 2e Exploitation \& energy indicators of oper. unit in the cultivation of maize

\begin{tabular}{|c|c|c|c|c|c|c|}
\hline $\begin{array}{c}\text { Aggregate } \\
\text { cultivation } \\
\text { of crops }\end{array}$ & $\begin{array}{c}\text { Working } \\
\text { speed } \\
\text { unit } \\
\left(\mathrm{km} \mathrm{h}^{-1}\right)\end{array}$ & $\begin{array}{c}\text { Fuel } \\
\text { consumption } \\
\left(1 \mathrm{~h}^{-1}\right)\end{array}$ & $\begin{array}{c}\text { Fuel } \\
\text { consumption } \\
\left(1 \mathrm{ha}^{-1}\right)\end{array}$ & $\begin{array}{c}\text { Energy } \\
\text { consumption } \\
\left(\mathrm{MJ} \mathrm{ha}^{-1}\right)\end{array}$ & $\begin{array}{c}\text { Working } \\
\text { width } \\
(\mathrm{m})\end{array}$ & $\begin{array}{c}\text { Technical } \\
\text { productivity } \\
\left(\mathrm{ha} \mathrm{h}^{-1}\right)\end{array}$ \\
\hline $\mathrm{Xsr}$ & 3.5 & 4.8 & 10.0 & 410.0 & 2.10 & 0.44 \\
\hline
\end{tabular}

Tab $2 \mathrm{f}$ Exploitation and energy parameters of a unit in the protection from weeds and plant diseases

\begin{tabular}{|c|c|c|c|c|c|c|}
\hline $\begin{array}{c}\text { Unit in } \\
\text { crop } \\
\text { protection }\end{array}$ & $\begin{array}{c}\text { Working } \\
\text { speed } \\
\text { unit } \\
\left(\mathrm{km} \mathrm{h}^{-1}\right)\end{array}$ & $\begin{array}{c}\text { Fuel } \\
\text { consumption } \\
\left(\mathrm{l} \mathrm{h}^{-1}\right)\end{array}$ & $\begin{array}{c}\text { Fuel } \\
\text { consumption } \\
\left(1 \mathrm{ha}^{-1}\right)\end{array}$ & $\begin{array}{c}\text { Energy } \\
\text { consumption } \\
\left(\mathrm{MJ} \mathrm{ha}^{-1}\right)\end{array}$ & $\begin{array}{c}\text { Working } \\
\text { width } \\
(\mathrm{m})\end{array}$ & $\begin{array}{c}\text { Technical } \\
\text { productivity } \\
\left(\mathrm{ha} \mathrm{h}^{-1}\right)\end{array}$ \\
\hline $\mathrm{Xsr}$ & 4.0 & 2.8 & 1,75 & 71,75 & 8,0 & 1,6 \\
\hline
\end{tabular}

Table $2 \mathrm{~g}$ Exploitation and energy indicators of operation of the unit in the plant mass silage maize

\begin{tabular}{|c|c|c|c|c|c|c|}
\hline $\begin{array}{c}\text { Aggregate } \\
\text { silage in } \\
\text { the silo } \\
\text { weight }\end{array}$ & $\begin{array}{c}\text { Working } \\
\text { speed } \\
\text { unit } \\
\left(\mathrm{km} \mathrm{h}^{-1}\right)\end{array}$ & $\begin{array}{c}\text { Fuel } \\
\text { consumption } \\
\left(1 \mathrm{~h}^{-1}\right)\end{array}$ & $\begin{array}{c}\text { Fuel } \\
\text { consumption } \\
\left(1 \mathrm{ha}^{-1}\right)\end{array}$ & $\begin{array}{c}\text { Energy } \\
\text { consumption } \\
\left(\mathrm{MJ} \mathrm{ha}^{-1}\right)\end{array}$ & $\begin{array}{c}\text { Working } \\
\text { width } \\
(\mathrm{m})\end{array}$ & $\begin{array}{c}\text { Technical } \\
\text { productivity } \\
\left(\mathrm{ha} \mathrm{h}^{-1}\right)\end{array}$ \\
\hline $\mathrm{Xsr}$ & 1,8 & 6,2 & 88,60 & 3632.6 & 0.70 & 0.07 \\
\hline
\end{tabular}

The primary tillage (ploughing) was carried out after removing the potatoes with the tractor with power $\mathrm{P}=31 \mathrm{~kW}$ and the aggregate with double ploughshare. Aggregate recorded an average operating speed of $4.8 \mathrm{~km} \mathrm{~h}^{-1}$, with the consumption of diesel fuel in the amount of $4.21 \mathrm{~h}^{-1}$ and $281 \mathrm{~h}^{-1}$.

Additional tillage is performed after primary treatment, with a tractor of $\mathrm{P}=31 \mathrm{~kW}$ and rototiller $(\mathrm{R}=1.45 \mathrm{~m})$. Random average speed of $3.5 \mathrm{~km} \mathrm{~h}^{-1}$ unit has achieved the technical productivity of $0.36 \mathrm{ha} \mathrm{h}^{-1}$, with a power consumption of $524.8 \mathrm{MJ} \mathrm{ha}^{-1}$. The lowest power consumption was achieved in working operations, waste mineral fertilizers in the amount of $22.55 \mathrm{MJ} \mathrm{ha}^{-1}$.

The highest consumption of fuel and energy has achieved aggregate in silage corn plant mass, amounting to $88.601 \mathrm{ha}^{-1}$, which represents the energy consumption of $3632.6 \mathrm{MJ} \mathrm{ha}^{-1}$. Increased consumption unit (tractor $44 \mathrm{~kW}$ ) + carried silo single row harvester) was due to the significant yield of maize plants $\left(66840 \mathrm{~kg} \mathrm{ha}^{-1}\right)$, plant density, height stems and less bandwidth forage harvester.

Energy analysis results. In the Table 3 the results of power consumption in the completed working operations is presented. Results of energy consumption were analysed based on consumption of diesel fuel $\mathrm{Qh}\left(\mathrm{l} \mathrm{h}^{-1}\right)$, technical efficiency unit Wh $\left(\mathrm{ha} \mathrm{h}^{-1}\right)$ of fuel consumption QHA $\left(1 \mathrm{ha}^{-1}\right)$ and total consumption of diesel fuel Eha $\left(\mathrm{MJ} \mathrm{ha}^{-1}\right)$. 
Table 3. Energy use in operations performed operations

\begin{tabular}{|c|c|c|c|c|}
\hline Aggregate & $\begin{array}{c}\text { The fuel } \\
\text { consumption } \\
\mathrm{Q}_{\mathrm{ha}}\left(1 \mathrm{ha}^{-1}\right)\end{array}$ & $\begin{array}{c}\text { Total } \\
\text { energy fuel } \\
\left(\mathrm{MJ} \mathrm{ha}^{-1}\right)\end{array}$ & $\begin{array}{l}\text { Productivity } \\
\qquad\left(\mathrm{ha} \mathrm{h}^{-1}\right)\end{array}$ & $\begin{array}{c}\text { Fuel } \\
\text { consumption } \\
\text { Qh }\left(1 \mathrm{~h}^{-1}\right)\end{array}$ \\
\hline Tractor+double plow & 28.0 & 1148.0 & 0.15 & 4.2 \\
\hline Tractor + tiller & 12.8 & 524.8 & 0.36 & 4.6 \\
\hline Tractor+spreader NPK & 0.55 & 22.55 & 5.12 & 2.8 \\
\hline Tractor+sowing machine & 8.0 & 328.0 & 0.35 & 2.8 \\
\hline Tractor+cultivator 3R & 11.0 & 451.0 & 0.44 & 4.8 \\
\hline Tractor+sprayer $8 \mathrm{~m}$ & 1.75 & 71.75 & 1.6 & 2.8 \\
\hline Irrigation (6) & $4.5 \times 6=27$ & 1107.0 & I & 1.5 \\
\hline Tractor+forage harvester & 88.60 & 3632.6 & 0.07 & 6.2 \\
\hline Tractor fort rumpling & 35.5 & 1455.5 & I & 3.5 \\
\hline TOTAL & 213.2 & 8741.0 & l & l \\
\hline
\end{tabular}

The present energy-parameters of the operations have been processed based on the fuel consumption per unit area $\mathrm{Q}_{\mathrm{h}}\left(1 \mathrm{~h}^{-1}\right)$ and the $\mathrm{Q}_{\mathrm{ha}}\left(1 \mathrm{ha}^{-1}\right)$. The parameters are processed on the basis of the energy value of the diesel fuel $41 \mathrm{MJ}$ $\mathrm{I}^{-1}$ or the energy value of the silage of $5.6 \mathrm{MJ} \mathrm{kg}^{-1}$.

Energy inputs. Energy inputs $\left(\mathrm{MJ} \mathrm{ha}^{-1}\right)$ in the preparation of corn silage were determined based on projected energy consumption in the technological system of production and storage silage. $\mathrm{Na}$ the basis of the research results (Table 3) in total direct inputs $(41.5 \%)$ have the largest share inputs consumption fuel of $88.601 \mathrm{ha}^{-1}$ and energy of $3632.6 \mathrm{MJ} \mathrm{ha}^{-1}$, at ensiling corn plant mass. When compaction (trampling) silo mass inputs accounted for (16.6\%) with consumption of diesel fuel of $35.51 \mathrm{ha}^{-1}$ and energy of 1,455.5 MJ ha' $\mathrm{Mh}^{-1}$. The smallest of inputs $(0.26 \%)$ were achieved in the work unit in wastage of fertilizer, with diesel consumption of $0.551 \mathrm{ha}^{-1}$, which represents the energy consumption of $22.55 \mathrm{MJ} \mathrm{ha}^{-1}$.

Energy output. Calculation of energy output $\left(\mathrm{kg} \mathrm{ha}^{-1}\right)\left(\mathrm{M} \mathrm{ha}^{-1}\right)$ depends on the type of production. In the production of animal feed output energy is defined through the achieved yield and energy value produced nutrients (hay, haylage, silage). Haylage has a relatively high energy value of oat 0.441 units per kilogram or 5.04 MJ kg-1 (Radovanovic and Rajic, 1990), and the energy value of corn silage is $5.6 \mathrm{MJ} \mathrm{kg}^{-1}$. Based on the research results in production and storage of silage corn in 2012 when irrigated yield ensiled plant material(silage) amounted to $66.840 \mathrm{~kg} \mathrm{ha}^{-1}$. Energy production value $\left(\mathbf{M J} \mathbf{h a}^{-1}\right)=\mathbf{6 6 8 4 0} \mathrm{kgha}^{-1}$; $5.6 \mathrm{MJ} \mathrm{kg}^{-1}=374304 \mathrm{MJ} \mathrm{ha}^{-1}$.

Energy parameters. In the process of energy analysis was performed using the methodology given by Ortiz-Canava-and-a Hernanz (1999) which provides for the determination of the energy input and energy output, based on the values of energy consumed and the resulting yield and given energy equivalents. Based on the obtained values may be determined by the specific energy input, energy ratio and energy productivity. 
$\begin{array}{ll}\text { The specific energy input }(\mathrm{EL}) & =\frac{8.741(\mathrm{MJ} / \mathrm{ha})}{66.840(\mathrm{~kg} / \mathrm{ha}}=0.13\left(\mathrm{MJ} \mathrm{kg}^{-1}\right) \\ \text { Energy relationship (ER) } & =\frac{374.304(\mathrm{MI} / \mathrm{ha})}{8.741(\mathrm{MI} / \mathrm{ha}}=42.80 \\ \text { Energy productivity }(\mathrm{EP}) & =\frac{66.840 \mathrm{~kg} / \mathrm{ha})}{8.741(\mathrm{MI} / \mathrm{ha})}=7.65\left(\mathrm{~kg} \mathrm{MJ}^{-1}\right)\end{array}$

Energy inputs can be quantified according to their energy value and intensity. All the energy inputs in crop production can be divided into direct and indirect energy inputs. Calculating the energy output depends on the type of plant production. In the case of the production of animal feed in livestock output power is defined through the achieved yield and energy value of a given nutrient.

\section{CONCLUSIONS}

Sowing of corn silage is done with the tractor aggregate $(\mathrm{P}=28 \mathrm{~kW})$, with the row spacing between the plants of $70 \mathrm{~cm}$; the distance $18 \mathrm{~cm} ; 75.000$ plants per hectare, with the average of $28.01 \mathrm{ha}^{-1}$; energy consumption of $1.148,0 \mathrm{MJ}$ $\mathrm{ha}^{-1}$. In the tillage the diesel fuel consumption amounted of $12.81 \mathrm{ha}^{-1}, 524.8 \mathrm{MJ}$ $\mathrm{ha}^{-1}$ respectively; with the application of mineral fertilizers, the average consumption of diesel fuel stood at $0.55 \mathrm{l} \mathrm{ha}^{-1} ; 22.55 \mathrm{MJ} \mathrm{ha}^{-1}$ respectively. The highest consumption of diesel fuel was achieved with the ensiling of plant mass, which was in average $88.61 \mathrm{ha}^{-1}$, which represents the energy consumption of $3632 \mathrm{MJ} \mathrm{ha}^{-1}$. The total consumption of diesel fuel amounted $213 \mathrm{l} \mathrm{ha}^{-1} ; 8741.2$ $\mathrm{MJ} \mathrm{ha}^{-1}$, with the yield of $66.840 \mathrm{~kg} \mathrm{ha}^{-1}$, and the energy value of $374304 \mathrm{MJ}$.

The success of ensiling depends on the lactic-acid fermentation, anaerobic environment, moisture biomass and bacterial fermentation.

Ensiling includes more operations consist in ensiling plant mass, transport silage mass, rapid filling, compaction, conservation of silage mass. In the process of ensiling, filling silos or silo trench is performed continuously with constant trampling and compaction. After completion of the filling and compacting silage in the silo trench done we are covering with polythene sheeting or tarpaulins.

Silage of high forage crops of maize, sorghum and sunflower is done with combine harvesters who have special adaptive devices adapters. Mounted harvesters can be a single row or double row, are aggregated to a tractor power 30-50 kW. Mounted single and double row harvesters are represented in smaller areas.

For the process of the silage from corn cobs, the harvester sets the adapter without cutting device, without lead chains or straps. In this case, the manifold mass placed rollers, their rotation torn clips from corn stalks and directing them towards the conveyor remains in the accompanying transportation.

Forage harvesting to a large extent depends on the bandwidth combine that represents the amount of plant mass that gets on fire hacking and is expressed in $\mathrm{kg} \mathrm{s}^{-1}$. Throughput combine depends on the structural solutions, the type and condition of crops, engine power, setting combine harvesters, silo capacity chips, the number of revolutions silo chips, the number of knives chips and chopped length and mass organizations of transport. 


\section{REFERENCES}

Cobic, T., Bacvanski, S. Vucetic, S. (1983): Production and use of silage for animal feed. [Proizvodnja i koriscenje silaze u ishrani stoke]. Nolit, Belgrade.

Dinic, B. Djordjevic, N., (2005): Preparation and use of silage for livestock feeding [Pripremanje i koriscenje silaze]. The Institute of Agricultural Research in Belgrade, pp127.

Helander, C. (2014): Forage Feeding in Intensive Lamb Production. Faculty of Veterinary Medicine and Animal Science, Department of Animal Environment and Health, Doctoral Thesis. Swedish University of Agricultural Sciences, Skara, pp 73.

Jugovic, M. (2012): The study of optimal parameters in forage silaging. [Istraživanje optimalnih parametara pri sjenažiranju travne mase]. Master thesis. University of Belgrade, Faculty of Agriculture, Belgrade, p 1-53.

Jugovic, M., Radivojevic, D., Lalovic, M., Trifkovic, J. (2014): Effect of different haylage lines on haylage chemical composition. Fifth International Scientific Agricultural Symposium „Agrosym 2014“, Jahorina, Bosnia and Herzegovina, p 104-108.

Koprivica, R.; Thaqi, A.; Shark, A.; Kida, S. (2010): Exploitation properties of halfdrawn forage harvester "corner machinery 1300" in preparing alfalfa silage, XXI Scientific-expert conference on agro industry. Proceedings. 29 September October 2, 2010, Neum, Bosnia and Herzegovina 2010 p. 271-278.

Lulo, M., Gavric, B., Skaljic, S., Mitrovic, D. (1984): Modern technology in the harvest and transport of fruit [Savremena tehnika u berbi i transport plodova voca]. International Agricultural Symposium, Neum, 1984.

Mitrovic, D. (2012): Mechanization in Agriculture [Mehanizacija u poljoprivredi], University of Montenegro, Biotechnical Faculty, Podgorica, pp 284.

Ortiz-CanavateJ., HernanzJ.L. (1999): Analysis and Energy Saving, Energy for Biological Systems, CIGR Handbook.

Ronald, George, J. (1994): Extension Publications: Forage and Grain Crops. Dubuque, Iowa: Kendall/Hunt, p.152.

Wood, Brian J.B. (1997): Microbiology of Fermented Foods. Springer US, pp. 852. 